\title{
Does zinc with and without iron co- supplementation have effect on motor and mental development of children? A systematic review and meta-analysis
}

Firoozeh Sajedi ${ }^{1}$, Soheila Shahshahani ${ }^{1}$, Hesam Ghiasvand ${ }^{1,2}$, Zahra Mosallanezhad ${ }^{3,4}$ and Shiva Fatollahierad ${ }^{1 *}$ (D)

\begin{abstract}
Background: Effects of zinc with and without iron co-supplementation on child development are uncertain therefore the aims of this systematic review were to explore whether supplementation with zinc alone and zinc with iron in children aged 0-5 years old have beneficial or adverse effects on their mental and motor development.

Method: We searched MEDLINE, EMBASE, Cochrane Central Register of Controlled Trials, CINAHL, Web of Science and Scopus until July 2020 and included randomized controlled trials, which assessed effects of zinc supplementation with and without iron in children less than 5 years old on mental and motor development. Data were pooled by random effects model and the Standardized Mean Differences (SMDs) with 95\% confidence interval were estimated. The heterogeneity was assessed by $\mathrm{l}^{2}$.

Results: Twenty-five studies with 11,559 participants were eligible to be included in this systematic review. Metaanalysis was conducted with eight articles that used Bayley Scales of Infant and Toddler Development II. We concluded that zinc alone and zinc with iron co-supplementation do not have beneficial or adverse effect on child mental and motor development at 6 and 12 months of age with low to moderate quality of the evidence. Furthermore, Zinc supplementation does not have any long term effect on child development in preschool and school age children.

Conclusion: Most included studies did not show the efficacy of zinc with and without iron co-supplementation on child mental and motor development up to 9 years old age. Further Randomized Controlled Trials (RCTs) need to be taken into considerations the context-based differences between countries with special focus on socioeconomic differences.
\end{abstract}

Keywords: Zinc, Iron, Child, Development

\footnotetext{
* Correspondence: sh.fatollahie.rad@gmail.com

'Pediatric Neurorehabilitation Research Center, University of Social Welfare and Rehabilitation Sciences, Tehran, Iran

Full list of author information is available at the end of the article
}

(C) The Author(s). 2020 Open Access This article is licensed under a Creative Commons Attribution 4.0 International License, which permits use, sharing, adaptation, distribution and reproduction in any medium or format, as long as you give appropriate credit to the original author(s) and the source, provide a link to the Creative Commons licence, and indicate if changes were made. The images or other third party material in this article are included in the article's Creative Commons licence, unless indicated otherwise in a credit line to the material. If material is not included in the article's Creative Commons licence and your intended use is not permitted by statutory regulation or exceeds the permitted use, you will need to obtain permission directly from the copyright holder. To view a copy of this licence, visit http://creativecommons.org/licenses/by/4.0/ The Creative Commons Public Domain Dedication waiver (http://creativecommons.org/publicdomain/zero/1.0/) applies to the data made available in this article, unless otherwise stated in a credit line to the data. 


\section{Background}

Child development is one of the most important aspects of pediatrics. The brain in early years of life is more vulnerable and has high plasticity [1]. Therefore, there is a pressing need to prevent developmental delay by conducting early interventions in infants and preschool children [2, 3]. Nutrition is one of the influential domains on child development $[4,5]$. Zinc is a crucial micronutrient in the body which has high concentrations in synaptic vesicles of the glutamatergic neurons in the hippocampus and olfactory bulb [6]. It has also a significant role in DNA transcription, and subsequently brain development $[7,8]$.

The prevalence of zinc inadequate dietary intake varies between $7.5 \%$ in high income countries and 30\% in South Asia. In Iran, $10.9 \%$ of 3-6 years old children were zinc deficient [9]. Zinc deficiency in 1-4 years old children in Mexico was 28.1\% [10], and 59.09\% of children less than 5 years old were zinc deficient in rural Nigeria. This difference of zinc deficiency prevalence could originates from varying consumption of animal-protein and high-phytate diets [11].

Exclusively breastfed infants can take required amount of zinc from breast milk in their first 6 months of life. However, after 6 months of age, the mother's milk should be complemented with foods rich in zinc [12]. Apart from zinc rich foods, zinc fortification of foods and zinc supplementation can also increase zinc plasma concentration $[13,14]$. Hence to reach zinc requirements, children with poor nutrition may need zinc supplementation [15].

The role of zinc in child development has been analyzed in several studies with mixed results. We have summarized the results of some systematic reviews in this regard. In a systematic review, Gogia et al. (2012) included 13 trials and identified that zinc had no significant effects on child development. Eight of the studies evaluated child development using Bayley Scales of Infant and Toddler Development (BSID). The results of their meta-analysis showed that the mean difference in Mental Development Index (MDI) and Psychomotor Developmental Index (PDI) was -0.50 and 1.54 between zinc and placebo groups respectively at 12 month of age. The $p$ values were insignificant with high levels of heterogeneity [16]. In another meta-analysis, Nissensohn et al. (2013) examined effects of zinc on MDI and PDI in 0-12 months old children. These authors also found that MDI and PDI were not significantly different in intervention and control groups [17].

Furthermore, some studies showed that zinc may decrease serum iron [18] and ferritin concentration [19] and Zinc co- supplementation with iron could interfere with absorption of both micronutrients [20, 21]. However some studies showed the beneficial effects of zinc with iron co-supplementation on child development [22, 23].

Effects of zinc supplementation on childhood development in 0-5 years old children were last assessed in 2012 however in this systematic review, we retrieved RCTs until July 2020 which supplemented children up to 5 years old and assessed their development in 0-5 years old and school- age. Therefore, we systematically reviewed the existing literature to address whether zinc alone and zinc co-supplementation with iron in children up to 5 years of age had any short or long term effects on child mental and motor development.

\section{Methods}

\section{Search strategy and selection criteria}

We retrieved the studies through searching the following databases and search engines: MEDLINE (Ovid), EMBASE (Ovid), Cochrane Central Register of Controlled Trials (CENTRAL), CINAHL (EBSCO), Web of Science and Scopus. References of included studies and previous related review articles were screened in order to identify other possible relevant studies. Databases of registered clinical trials including clinicaltrials.gov, WHO International Clinical Trials Registry Platform (ICTRP) and ISRCTN Registry were also screened. Furthermore, The American Journal of Clinical Nutrition was hand searched for other potential related articles. Medical Subject Headings (MeSH terms) and text words were used to search databases. The time span for searching was from inception initially to July 2017 and then updated to July 2020. We only included published studies with English abstracts. We used Google Translate to translate the non- English retrieved studies to English. Supplementary Table (1) depicts the search strategy in Ovid MEDLINE.

We included randomized controlled trials (RCTs) with randomization at either an individual or cluster level. The participants were children $0-5$ years old at the time of supplementation without having HIV, developmental delay or developmental disorders such as autism, attention deficit hyperactivity disorder (ADHD), or intellectual disability. Furthermore, RCTs which supplemented children before 5 years of age but assessed them with developmental tests in school age were also included. The interventions of included studies were oral supplementation of zinc alone or zinc with iron, given on an intermittent or daily basis compared with either a placebo or no supplementation or with iron without zinc. We excluded studies that investigated food or formula milk fortification with zinc, zinc rich diet and parenteral zinc supplementation. Our primary outcome was the effect of zinc alone and in combination with iron supplementation in children $0-5$ years of age on their mental and motor development in 0-5 year old and school- age. 


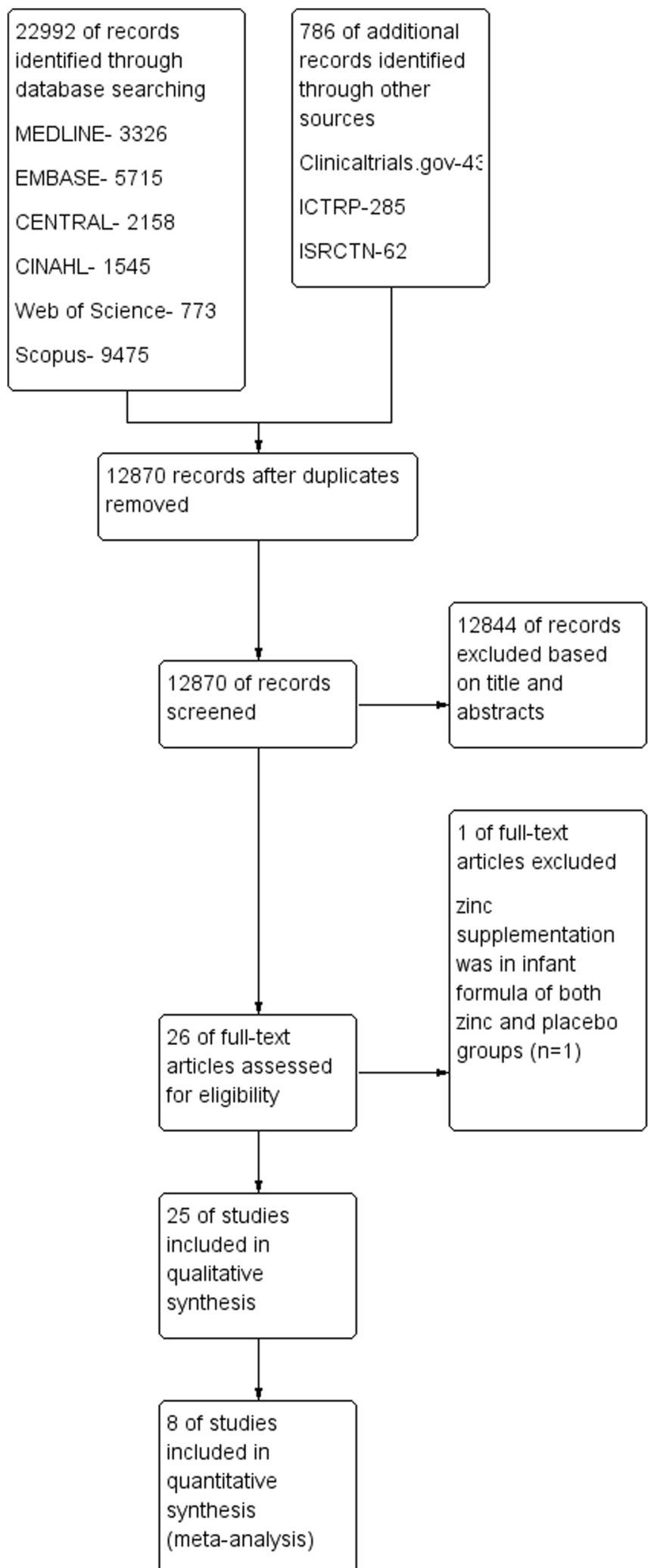

Fig. 1 Study flow diagram 


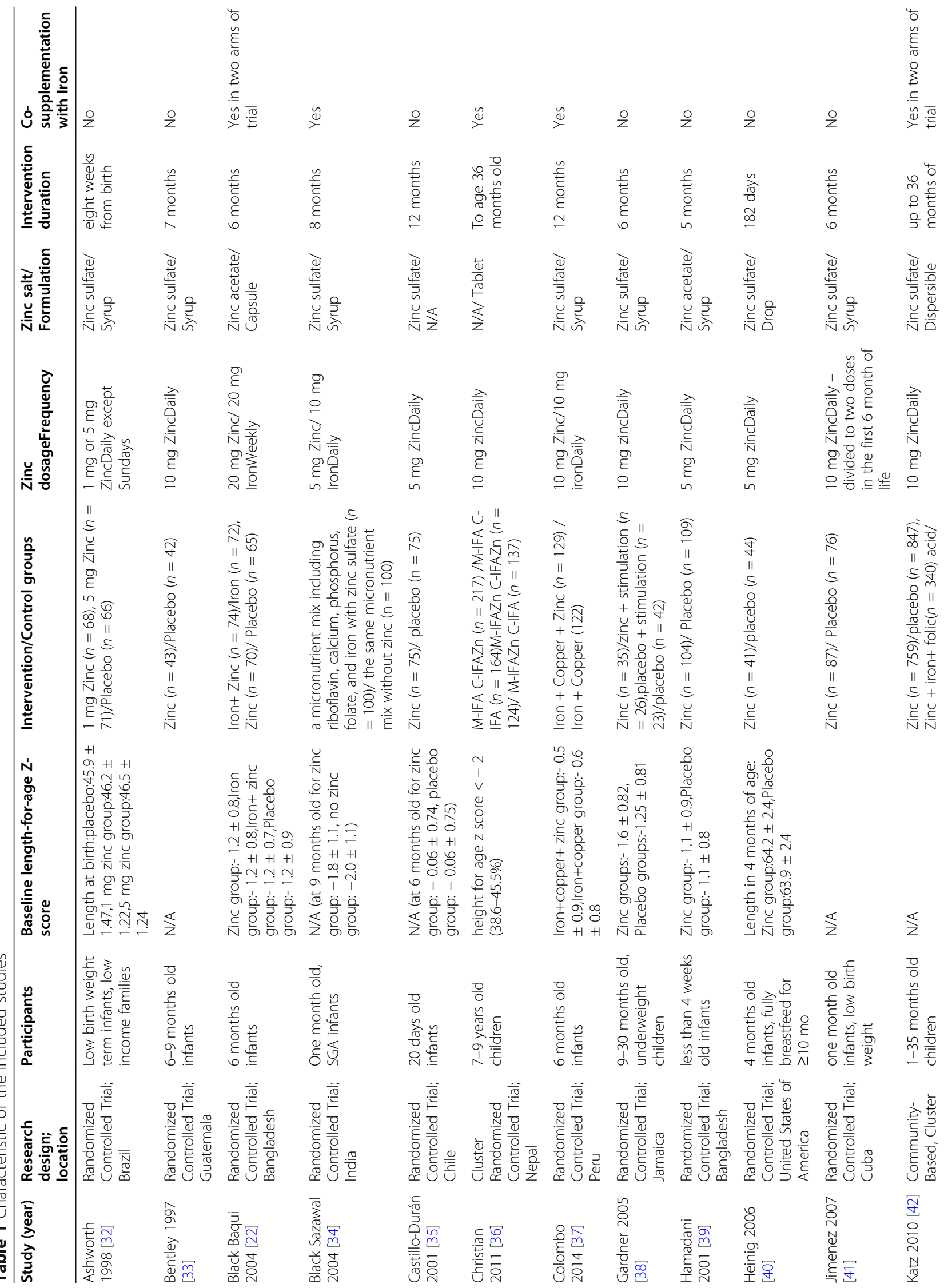




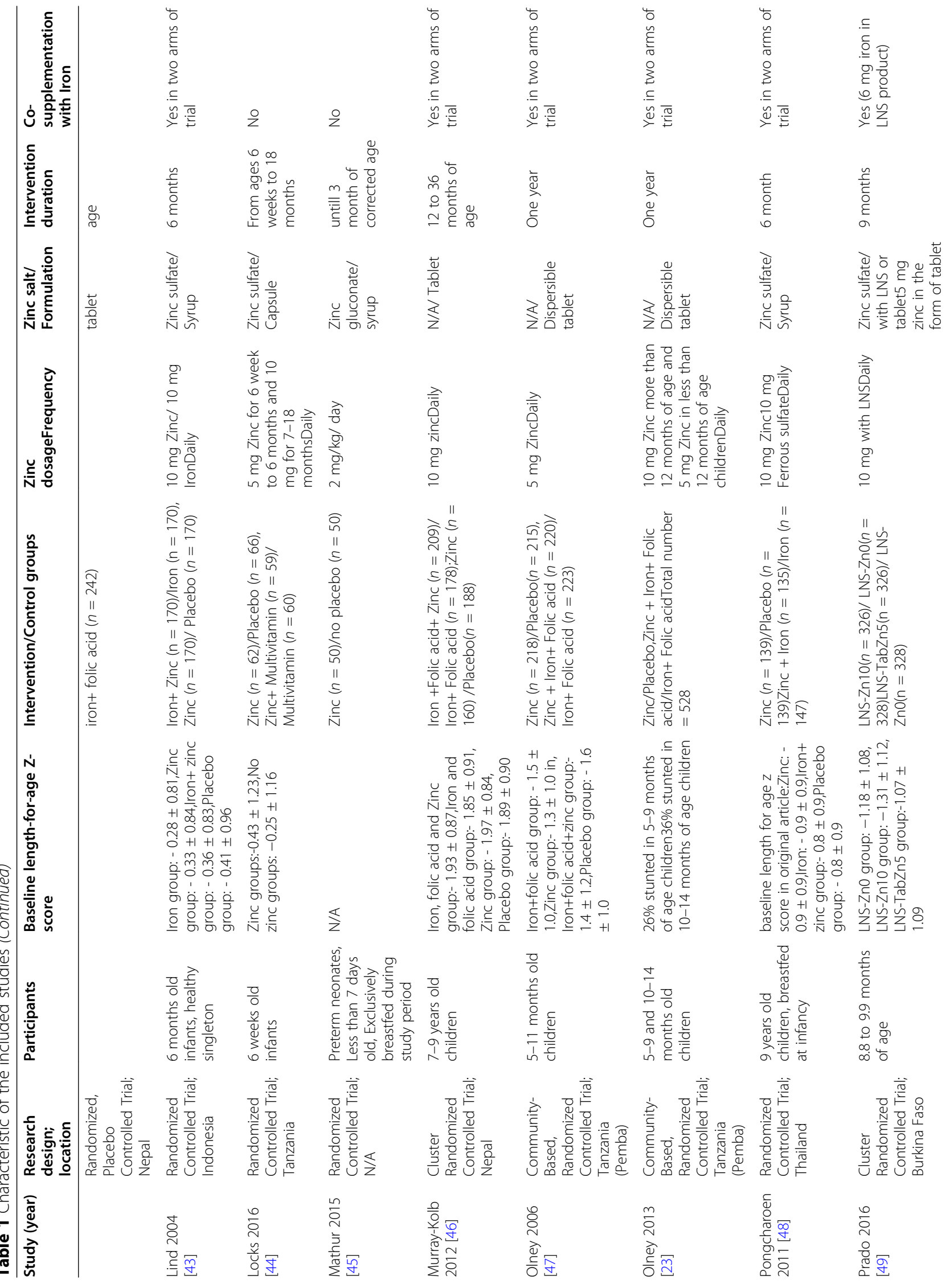




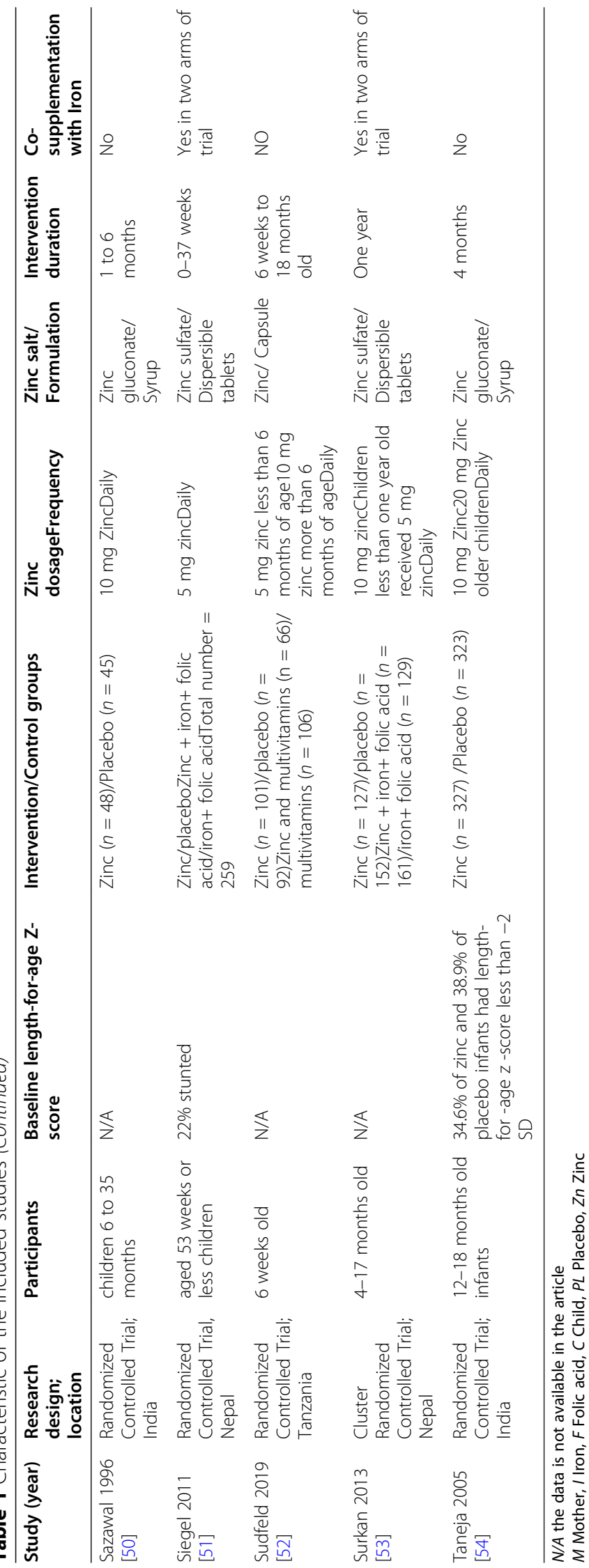


.Table 2 Results of the included studies

\begin{tabular}{|c|c|c|c|c|}
\hline Study (year) & Outcome & Assessment tool & $\begin{array}{l}\text { Assessment } \\
\text { time }\end{array}$ & Conclusion \\
\hline $\begin{array}{l}\text { Ashworth } \\
1998[32]\end{array}$ & $\begin{array}{l}\text { Development (motor, } \\
\text { mental and behavior) }\end{array}$ & BSID-II & $\begin{array}{l}6 \text { and } 12 \text { month } \\
\text { of age }\end{array}$ & MDI: no difference PDI: no difference \\
\hline $\begin{array}{l}\text { Bentley } 1997 \\
\text { [33] }\end{array}$ & Motor development & Time sampling observation method & $\begin{array}{l}\text { Enrollment, } 3 \\
\text { and } 7 \text { months of } \\
\text { supplementation }\end{array}$ & $\begin{array}{l}\text { Motor: no difference at } 3 \text { months follow up } \\
\text { and better in zinc group at } 7 \text { months follow } \\
\text { up(more time playing, sitting up and less } \\
\text { time lying down and crying) }\end{array}$ \\
\hline $\begin{array}{l}\text { Black Baqui } \\
2004[22]\end{array}$ & $\begin{array}{l}\text { Development (motor, } \\
\text { mental and behavior) }\end{array}$ & BSID-II & $\begin{array}{l}\text { Baseline and } 12 \\
\text { month of age }\end{array}$ & $\begin{array}{l}\text { MDI: better in Iron+ zinc groupPDI: no } \\
\text { difference }\end{array}$ \\
\hline $\begin{array}{l}\text { Black Sazawal } \\
2004[34]\end{array}$ & $\begin{array}{l}\text { Development (motor, } \\
\text { mental and behavior) }\end{array}$ & BSID-II & $\begin{array}{l}6 \text { and } 10 \\
\text { months of age }\end{array}$ & MDI: no differencePDI: no difference \\
\hline $\begin{array}{l}\text { Castillo-Durán } \\
2001[35]\end{array}$ & $\begin{array}{l}\text { Development (motor } \\
\text { and mental) }\end{array}$ & BSID-II & $\begin{array}{l}6 \text { and } 12 \\
\text { months of age }\end{array}$ & MDI: no differencePDI: no difference \\
\hline $\begin{array}{l}\text { Christian } \\
2011[36]\end{array}$ & $\begin{array}{l}\text { Motor (fine and gross) } \\
\text { functioninggeneral } \\
\text { intelligenceexecutive } \\
\text { functioning }\end{array}$ & $\begin{array}{l}\text { MABC and finger tapping testUNITStroop } \\
\text { test, backward digit span, go/no-go tasks }\end{array}$ & $7-9$ years of age & Motor: no differenceMental: no difference \\
\hline $\begin{array}{l}\text { Colombo } \\
2014[37]\end{array}$ & $\begin{array}{l}\text { Development (motor } \\
\text { and mental) }\end{array}$ & BSID-II & $\begin{array}{l}\text { Baseline, } 12 \text { and } \\
18 \text { months of } \\
\text { age }\end{array}$ & MDI: no differencePDI: no difference \\
\hline $\begin{array}{l}\text { Gardner } 2005 \\
\text { [38] }\end{array}$ & Development & $\begin{array}{l}4 \text { subscales of the Griffiths Mental } \\
\text { Development Scales }\end{array}$ & $\begin{array}{l}\text { Enrollment and } \\
6 \text { months follow } \\
\text { up }\end{array}$ & $\begin{array}{l}\text { Hand and eye coordination: better in zinc } \\
\text { group }\end{array}$ \\
\hline $\begin{array}{l}\text { Hamadani } \\
2001[39]\end{array}$ & $\begin{array}{l}\text { Development (motor } \\
\text { and mental) }\end{array}$ & BSID-II & $\begin{array}{l}7 \text { and } 13 \\
\text { months of age }\end{array}$ & $\begin{array}{l}7 \text { months assessment:MDI: no differencePDI: } \\
\text { no difference } 13 \text { months assessment:MDI: } \\
\text { worse in zinc groupPDI: no difference }\end{array}$ \\
\hline $\begin{array}{l}\text { Heinig } 2006 \\
{[40]}\end{array}$ & Motor development & Alberta Infant Motor Scale (AIMS) & $\begin{array}{l}4 \text { (baseline) and } \\
10 \text { months of } \\
\text { age }\end{array}$ & Gross motor development: no difference \\
\hline $\begin{array}{l}\text { Jimenez } 2007 \\
\text { [41] }\end{array}$ & $\begin{array}{l}\text { Development (motor } \\
\text { and mental) }\end{array}$ & BSID-II & $\begin{array}{l}\text { Baseline, } 3,6,9 \\
\text { and } 12 \text { months } \\
\text { of age }\end{array}$ & $\begin{array}{l}\text { MDI: no differencePDI: better in zinc group } \\
\text { at } 6 \text { months }\end{array}$ \\
\hline Katz 2010 [42] & $\begin{array}{l}\text { Age at first walking } \\
\text { unassisted }\end{array}$ & $\begin{array}{l}\text { Pictures of } 14 \text { sequential motor } \\
\text { milestones/ }\end{array}$ & $\begin{array}{l}\text { Weekly interview } \\
\text { with the child's } \\
\text { caregiver }\end{array}$ & $\begin{array}{l}\text { Mean age at first walking unassisted: no } \\
\text { difference }\end{array}$ \\
\hline $\begin{array}{l}\text { Lind } 2004 \\
{[43]}\end{array}$ & $\begin{array}{l}\text { Development (motor, } \\
\text { mental and behavior) }\end{array}$ & BSID-II & $\begin{array}{l}\text { Baseline and } 12 \\
\text { months of age }\end{array}$ & MDI: no differencePDI: no difference \\
\hline $\begin{array}{l}\text { Locks } 2016 \\
{[44]}\end{array}$ & $\begin{array}{l}\text { Development } \\
\text { (cognition, language, } \\
\text { and motor) }\end{array}$ & BSID-III & $\begin{array}{l}15 \text { months of } \\
\text { age }\end{array}$ & No difference in any domains of BSID-III \\
\hline $\begin{array}{l}\text { Mathur } 2015 \\
{[45]}\end{array}$ & Neurodevelopment & Amiel-Tison method & $\begin{array}{l}40 \text { weeks } \\
\text { conceptual age } \\
\text { and } 3 \text { month } \\
\text { corrected age }\end{array}$ & $\begin{array}{l}\text { Attention span: better in zinc group at } 40 \\
\text { weeks conceptual ageHyper-excitability: } \\
\text { higher number in control group at } 40 \text { weeks } \\
\text { conceptual age and } 3 \text { month corrected age }\end{array}$ \\
\hline $\begin{array}{l}\text { Murray-Kolb } \\
2012[46]\end{array}$ & $\begin{array}{l}\text { General } \\
\text { intelligenceexecutive } \\
\text { functioning }\end{array}$ & $\begin{array}{l}\text { UNITStroop test, backward digit span, go/ } \\
\text { no-go tasks }\end{array}$ & $7-9$ years of age & Motor: no differenceMental: no difference \\
\hline $\begin{array}{l}\text { Olney } 2006 \\
{[47]}\end{array}$ & $\begin{array}{l}\text { Motor development } \\
\text { (the time it took for } \\
\text { children to walk } \\
\text { unassisted) }\end{array}$ & $\begin{array}{l}\text { picture chart containing } 14 \text { gross motor } \\
\text { milestones based on the work of McGraw }\end{array}$ & $\begin{array}{l}\text { Every two week } \\
\text { for one year }\end{array}$ & Motor: no difference \\
\hline $\begin{array}{l}\text { Olney } 2013 \\
{[23]}\end{array}$ & $\begin{array}{l}\text { Development (motor, } \\
\text { social emotional, } \\
\text { exploratory behavior } \\
\text { and language) }\end{array}$ & $\begin{array}{l}\text { Picture chart containing } 14 \text { gross motor } \\
\text { milestones }\end{array}$ & $\begin{array}{l}\text { Every two week } \\
\text { for one year }\end{array}$ & $\begin{array}{l}\text { Gross motor: better in iron+ folic acid+ zinc } \\
\text { in } 5-9 \text { months group and better in iron+ } \\
\text { folic acid in 10-14 months groupMotor } \\
\text { activity: better in iron+ folic acid+ zinc in } \\
10-14 \text { months group }\end{array}$ \\
\hline Pongcharoen & Cognitive performance & Wechsler Intelligence Scale for Children- & 9 years old & Mental: no difference \\
\hline
\end{tabular}


Table 2 Results of the included studies (Continued)

\begin{tabular}{|c|c|c|c|c|}
\hline Study (year) & Outcome & Assessment tool & $\begin{array}{l}\text { Assessment } \\
\text { time }\end{array}$ & Conclusion \\
\hline & & $\begin{array}{l}\text { Raven's Colored Progressive Matrices } \\
\text { (CPM) }\end{array}$ & & \\
\hline $\begin{array}{l}\text { Prado } 2016 \\
\text { [49] }\end{array}$ & $\begin{array}{l}\text { Development (motor, } \\
\text { language, and } \\
\text { personal-social } \\
\text { development) }\end{array}$ & Developmental Milestones Checklist II & $\begin{array}{l}18 \text { months of } \\
\text { age }\end{array}$ & Motor: no difference \\
\hline $\begin{array}{l}\text { Sazawal } 1996 \\
\text { [50] }\end{array}$ & Activity levels & Observation and recording & $\begin{array}{l}12 \text { to } 23 \text { months } \\
\text { of age }\end{array}$ & Activity level: better in zinc group \\
\hline $\begin{array}{l}\text { Siegel } 2011 \\
{[51]}\end{array}$ & $\begin{array}{l}\text { Cognitive } \\
\text { development }\end{array}$ & $\begin{array}{l}\text { Information-processing measures that } \\
\text { were part of the FTII and the A-not-B Task }\end{array}$ & $\begin{array}{l}39 \text { and } 52 \text { week } \\
\text { old }\end{array}$ & Mental: no difference \\
\hline $\begin{array}{l}\text { Sudfeld } 2019 \\
\text { [52] }\end{array}$ & Development & $\begin{array}{l}\text { Koh's Block Design testVerbal Fluency } \\
\text { testEast African Neurodevelopment Tools }\end{array}$ & $6-8$ years old & $\begin{array}{l}\text { General intelligence: no differenceExecutive } \\
\text { function: no difference }\end{array}$ \\
\hline $\begin{array}{l}\text { Surkan } 2013 \\
\text { [53] }\end{array}$ & $\begin{array}{l}\text { Development (parental } \\
\text { report of Motor and } \\
\text { Language Milestones) }\end{array}$ & $\begin{array}{l}\text { Motor and language milestone } \\
\text { instruments were adaptedfrom the } \\
\text { Griffiths Mental Development Scale and } \\
\text { the MacArthur Communicative } \\
\text { Development Inventory }\end{array}$ & $\begin{array}{l}\text { Baseline and } \\
\text { three month } \\
\text { intervals for one } \\
\text { year. }\end{array}$ & Motor: no difference \\
\hline $\begin{array}{l}\text { Taneja } 2005 \\
{[54]}\end{array}$ & $\begin{array}{l}\text { Development (motor } \\
\text { and mental) }\end{array}$ & BSID-II & $\begin{array}{l}4 \text { months after } \\
\text { supplementation }\end{array}$ & MDI: no differencePDI: no difference \\
\hline
\end{tabular}

N/A the data is not available in the article

This study employed Preferred Reporting Items for Systematic Reviews and Meta-Analyses (PRISMA) [24] to identify relevant articles and report the screening process. Two reviewers screened titles and abstracts of the articles for selecting relevant studies. Full text of potentially eligible articles meeting inclusion criteria were read by the two reviewers for inclusion in the review. Any disagreement about selecting an article was resolved through discussion. Data extraction of included studies was carried out by two review authors using a form designed for this review. Any discrepancies between the extracted data were discussed to reach a consensus. The extracted data were imported to Review Manager 5.3 by one reviewer.

For each study, we collected data on the following domains: author, publication date, study design, location and setting of the study, intervention date, sample size, age range, nutritional status, baseline length-for-age zscore, co morbidities, inclusion and exclusion criteria, zinc dosage, frequency of zinc supplementation, type of zinc compound, duration of the intervention, co-interventions, outcomes, outcomes assessments tools, results, method of allocation and randomization, blinding of participants and outcome assessors, exclusion of participants after randomization and proportion of losses to follow-up.

Details of methods in some sub- studies were extracted from the original article as the authors did not fully explain the methods [25-27]. In some cases, extra information was obtained by communicating with corresponding authors of articles. Furthermore, two reviewers independently evaluated the risk of bias for all included studies using the Cochrane Collaborations' tool for assessing risk of bias in randomized trials [28, 29]. We

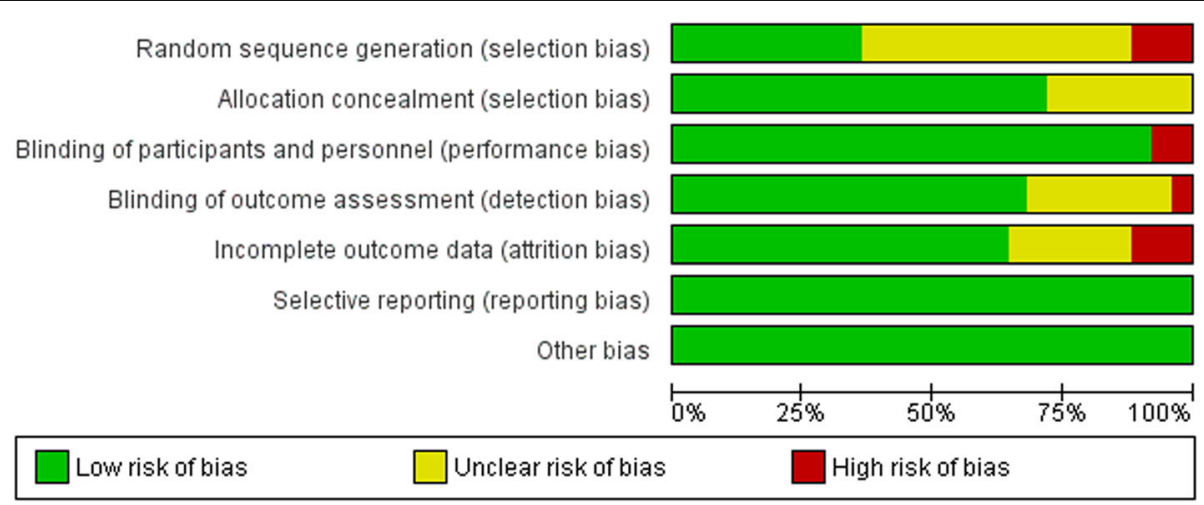

Fig. 2 Risk of bias summary 


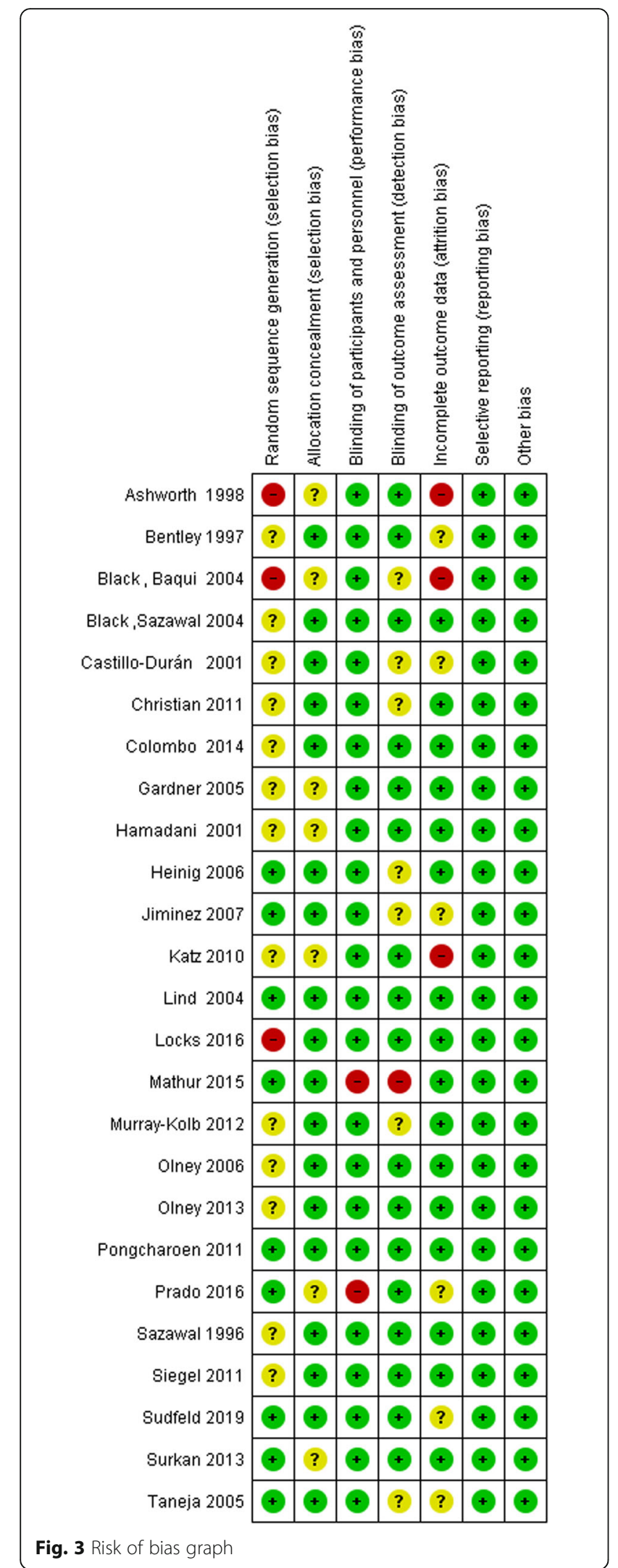

resolved any disagreement by discussion. The risk of bias tool assesses the following criteria: Random sequence generation (checking for possible selection bias), allocation concealment (checking for possible selection bias), blinding of participants and personnel (checking for possible performance bias), blinding of outcome assessment (checking for possible detection bias), incomplete outcome data (checking for possible attrition bias through withdrawals, dropouts, protocol deviations), selective reporting (checking for possible reporting bias) and other sources of bias. The reviewers' judgments were categorized as 'Low risk' of bias, 'High risk' of bias or 'Unclear risk' of bias. In addition, we applied GRADE criteria to assess the quality of evidence [30]. The GRADE Pro/GDT software was used to perform and illustrate the GRADE approach. We downgraded the high quality evidence by one level for serious concerns about risk of bias, inconsistency, indirectness, imprecision and publication bias criteria. The quality of each outcome is described as High, Moderate, and Low and very low based on these criteria. An $\mathrm{I}^{2}$ of more than $75 \%$ were considered high heterogeneity and on the condition that an outcome had high heterogeneity, the quality evidence was downgraded by one level. For determining the risk of bias of each outcome in a study, we defined three main domains in risk of bias tool. These domains were "random sequence generation", "allocation concealment" and "blinding of outcome assessment". If all three of them were low risk in a study, the outcome of that study was considered low risk. If one domain was unclear or high risk, the outcome of that study was considered unclear or high risk respectively. Finally, the risk of bias of each outcome between studies for GRADE quality was determined.

\section{Data synthesis and statistical analysis}

We performed a meta-analysis on articles that used BSID second edition. Because of the considerable diversity in methods of assessing development; we excluded other articles that applied non-BSID II developmental screening tools from statistical analysis.

We ran random effects model in studies encompassed continuous outcomes. The reason for conducting the random effects approach was the high level of I squarewhich is the main statistics for assessing the heterogeneity- and clinical heterogeneity. Publication bias was assessed using Egger's test and illustration with the funnel plot. We estimated the Standardized Mean Difference (SMD) with 95\% confidence interval through Review Manager 5.3 [31] and Metan command in STATA 14 . We conducted two main analyses. First we pooled data between zinc alone studies and the studies that had zinc alone arm in their multi arm interventions, to explore the effect of zinc without iron co- 
Table 3 Meta-analysis results

\begin{tabular}{|c|c|c|c|c|}
\hline Outcomes by time points of BSID assessments & Number of Trials & Sample Size & SMD $(95 \% \mathrm{Cl})$ & Heterogeneity Statistics \\
\hline \multicolumn{5}{|l|}{ Zinc Alone vs. Placebo } \\
\hline \multicolumn{5}{|l|}{6 Months: } \\
\hline $\mathrm{MDI}$ & 4 & 591 & $-0.18(-0.39 \text { to } 0.02)^{a}$ & $P^{2}=37.4 \%, X^{2}=4.79$ \\
\hline PDI & 4 & 591 & $0.17(-0.20$ to 0.55$)$ & $I^{2}=80.8 \%, X^{2}=15.60$ \\
\hline \multicolumn{5}{|l|}{12 Months: } \\
\hline MDI & 6 & 977 & $-0.08(-0.36$ to 0.19$)$ & $I^{2}=77.4 \%, X^{2}=22.14$ \\
\hline PDI & 6 & 977 & $0.30(-0.24$ to 0.83$)$ & $I^{2}=94.00 \%, X^{2}=80.23$ \\
\hline \multicolumn{5}{|l|}{ Zinc with Iron vs. Iron } \\
\hline \multicolumn{5}{|l|}{6 Months: } \\
\hline $\mathrm{MDI}$ & 2 & 359 & $0.09(-0.11$ to 0.30$)$ & $I^{2}=0.00, X^{2}=0.01$ \\
\hline PDI & 2 & 359 & $0.07(-0.14$ to 0.28$)$ & $I^{2}=0.00, X^{2}=0.42$ \\
\hline \multicolumn{5}{|l|}{12 Months: } \\
\hline MDI & 4 & 790 & $-0.03(-0.17$ to 0.11$)$ & $I^{2}=0.00, X^{2}=1.02$ \\
\hline PDI & 4 & 790 & $0.01(-0.24$ to 0.26$)$ & $I^{2}=66.40, X^{2}=8.94$ \\
\hline
\end{tabular}

a Significant at $10 \%$ level

supplementation on child development. Second pooling data were between zinc co-supplementation with iron trials and the multi arm intervention studies that had zinc with iron arm. All these analyses were done at both 6 and 12 months of age assessment time. If a study report was not in these two time points, we considered their data in the nearest assessment time points. The data of 7 months assessment times were considered in 6 months time point and 10,13 and 15 months' assessment times in 12 months time point for meta-analysis.

The significance level for assessing these analyses was 0.05 . As a result of small number of studies in each categorical variable, the sub-group analysis and sensitivity analysis were not performed. In addition, because of the small number of studies, it was not applicable to exclude articles with high risk of bias from meta-analysis.

\section{Results}

\section{Study selection}

The search resulted in 22,992 records. After removing duplicate articles and performing the screening phase, 25 RCT studies with 11,559 participants were eligible to be included in the systematic review. The study flow diagram is illustrated in Fig. 1.>

\section{Study characteristics}

The characteristics of studies are presented in Table 1. Eleven studies only supplemented children with zinc alone [32, 33, 35, 38-41, 44, 45, 50, 54] and four studies co-supplemented them with zinc and iron [34, 36, 37, 49]. Ten trials had three parallel arms that one arm received zinc and iron; another arm received iron; and the third arm received zinc alone $[22,23,42,43,46-48,51-$ 53].

With regard to child development assessment tools, nine studies assessed the child development by BSID second edition [22, 32, 34, 35, 37, 39, 41, 43, 54], one study evaluated the development by BSID third edition [44], and 15 studies used other developmental assessment tools [23, 33, 36, 38, 40, 42, 45-53]. Furthermore four studies were RCTs that supplemented children before the age of 5 years old and assessed their development in school age [36, 46, 48, 52]. The rest of the studies evaluated the development before the age of five. All of the included studies were in English however only one of the them was published in Spanish and Google Translate was used to translate it into English [41]. Table 2 depicts the results of the studies. Supplementary File 1 shows the characteristics of all included studies more comprehensively.

\begin{tabular}{|c|c|c|c|c|c|c|c|c|c|c|c|c|}
\hline & Study or Subgroup & \multicolumn{3}{|c|}{ Zinc alone } & \multicolumn{3}{|c|}{ Placebo } & \multicolumn{2}{|r|}{ Std. Mean Difference } & \multicolumn{2}{|r|}{$\begin{array}{c}\text { Std. Mean Difference } \\
\text { IV, Random, } 95 \% \mathrm{Cl}\end{array}$} & \\
\hline & Ashworth 1998 & 90.1 & 7.4 & 54 & 91.5 & 5.4 & 53 & $20.7 \%$ & $-0.21[-0.59,0.17]$ & & $\rightarrow$ & \\
\hline & Castillo-Durán 2001 & 90.19 & 5.6 & 57 & 90.8 & 7.8 & 52 & $21.0 \%$ & $-0.09[-0.47,0.29]$ & & $-\infty$ & \\
\hline & Hamadani 2001 & 98.4 & 7 & 103 & 98.4 & 6.51 & 109 & $31.6 \%$ & $0.00[-0.27,0.27]$ & & - & \\
\hline & Jiminez 2007 & 101 & 8.9 & 87 & 105 & 9 & 76 & $26.8 \%$ & $-0.45[-0.76,-0.13]$ & & -- & \\
\hline & Total $(95 \% \mathrm{Cl})$ & & & 301 & & & 290 & $100.0 \%$ & $-0.18[-0.39,0.02]$ & & 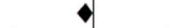 & \\
\hline & $\begin{array}{l}\text { Heterogeneity: } \operatorname{Tau}^{2}=0 \text {. } \\
\text { Test for overall effect: } z\end{array}$ & $\begin{array}{l}.02 ; \mathrm{Chi}^{2} \\
=1.73(\mathrm{P}\end{array}$ & $\begin{array}{l}=4.7 \\
=0.0\end{array}$ & $\begin{array}{l}4, d f=3 \\
08)\end{array}$ & $3(P=0$. & $19) ; 1^{2}=$ & $=37 \%$ & & & $\frac{1}{-4}$ & $\begin{array}{ccc}1 & 1 & 1 \\
\text { placebo } & 2 \\
\text { zinc alone }\end{array}$ & 4 \\
\hline
\end{tabular}




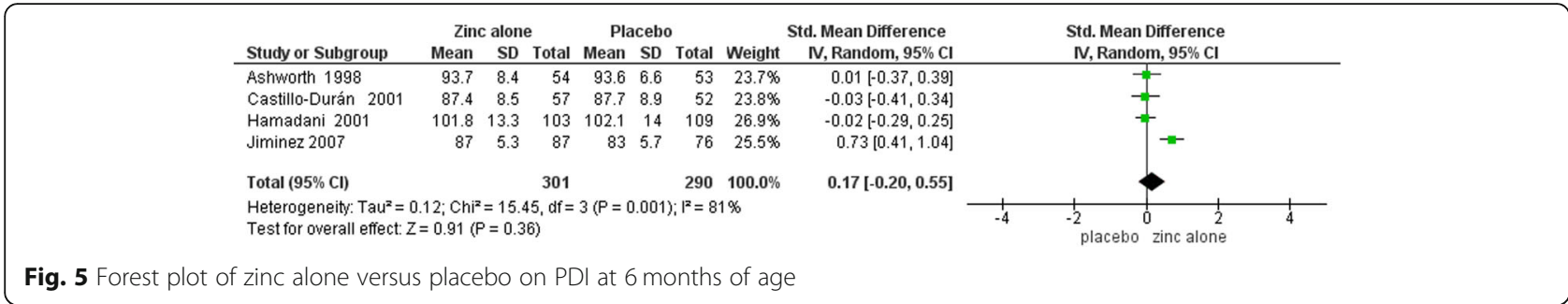

\section{Risk of bias in included studies}

Risk of bias of included studies was evaluated with Cochrane Risk of Bias Tool for Randomized Controlled Trials. In the random sequence generation domain, 13 articles had unclear risk [23, 33-39, 42, 46, 47, 50, 51], nine articles had low risk [40, 41, 43, 45, 48, 49, 52-54] and three studies had high risk of bias [22, 32, 44]. In addition, 18 articles had low risk of bias [23, 33-37, 40, $41,43-48,50-52,54]$, seven studies had unclear risk of bias [22, 32, 38, 39, 42, 49, 53] and no study had high risk of bias in allocation concealment domain. Two articles had a high-risk of bias $[45,49]$ in blinding of participants and personnel domain and the rest of the articles had low risk of bias. Furthermore, 17 studies had low risk of bias [23, 32-34, 37-39, 42-44, 47-53], seven articles had unclear risk of bias [22, 35, 36, 40, 41, 46, 54], and one study had high risk of bias [45] in blinding of outcome assessment domain. Three studies had high risk of bias [22, 32, 42], six trials had unclear risk of bias $[33,35,41,49,52,54]$ and 16 articles had low risk of bias in incomplete outcome data [23, 34, 36-40, 43-48, 50, 51, 53]. Figures 2 and 3 show the risk of bias summary and graph respectively.

In addition, four studies had high risk of bias [22, 32, $44,45]$, three studies had low risk of bias [43, 48, 52] and the rest of them had unclear risk of bias for developmental outcomes.

\section{Meta-analysis findings}

Meta-analyses with 8 articles that used BSID second edition were performed. We excluded the study conducted by Taneja et al. from analysis since the duration of zinc supplementation intake was different among children
[54]. We also excluded the $1 \mathrm{mg}$ zinc arm of Ashworth et al. study from our analysis since the dosage used in their study was lower than the minimum $5 \mathrm{mg}$ zinc dose used in the other studies. These Meta analyses assessed the effects of zinc on mental and motor domains of development at two time points (6 and 12 months old children). The developmental assessment times of most of the included studies were less than 12 months of age. Therefore, we could not analyze the developmental changes in children above one-year-old in meta-analysis.

Funnel plots for assessing publication bias had symmetrical appearances that are presented in supplementary Figures 1, 2, 3, 4, 5, 6, 7 and 8. Furthermore, the Egger's test results for all outcomes in both two time points (6 and 12 months) were also not statistically significant ( $P>0.05$ for all of the slopes) and they are presented in details in supplementary appendix. Table 3 demonstrates the results of meta-analysis. Forest plots of meta-analyses are presented in Figs. 4, 5, 6, 7, 8, 9, 10 and 11.

In meta-analysis of zinc alone versus placebo groups, four studies at 6 months assessment time and six trials in 12 months assessment time with BSID II were included. There is moderate quality evidence that MDI at 6 months of age was not different in zinc alone supplementation group compared with control group (SMD: $-0.18,95 \%$ CI: -0.39 to $0.02, p$ value: $0.08,591$ participants). There is low quality evidence that zinc alone had no beneficial or negative effect on MDI at 12 months of age (SMD: $-0.08,95 \%$ CI: - 0.36to 0.19, $P$ value: 0.56 , 977 participants).

Zinc alone supplementation had no impact on PDI at 6 months of age (SMD: $0.17,95 \%$ CI: -.0 .20 to $0.55, P$

\begin{tabular}{|c|c|c|c|c|c|c|c|c|c|c|c|c|}
\hline & Study or Subgroup & \multicolumn{3}{|c|}{ Zinc alone } & \multicolumn{3}{|c|}{ Placebo } & \multicolumn{2}{|r|}{ Std. Mean Difference } & \multicolumn{2}{|r|}{$\begin{array}{l}\text { Std. Mean Difference } \\
\text { IV, Random, } 95 \% \mathrm{Cl}\end{array}$} & \\
\hline & Ashworth 1998 & 106.9 & 12.1 & 46 & 109.1 & 12.2 & 44 & $14.7 \%$ & $-0.18[-0.59,0.23]$ & & $\rightarrow$ & \\
\hline & Black, Baqui 2004 & 104.7 & 8.3 & 49 & 102.7 & 13.5 & 45 & $15.0 \%$ & $0.18[-0.23,0.58]$ & & $=-$ & \\
\hline & Castillo-Durán 2001 & 90.9 & 10.5 & 57 & 88.9 & 9.1 & 52 & $15.6 \%$ & $0.20[-0.18,0.58]$ & & & \\
\hline & Hamadani 2001 & 103.1 & 11 & 97 & 106.4 & 9.3 & 101 & $18.0 \%$ & $-0.32[-0.60,-0.04]$ & & $=$ & \\
\hline & Jiminez 2007 & 108 & 9.2 & 87 & 113 & 8.9 & 76 & $17.2 \%$ & $-0.55[-0.86,-0.24]$ & & - & \\
\hline & Lind 2004 & 101 & 9.3 & 161 & 99 & 10 & 162 & $19.4 \%$ & $0.21[-0.01,0.43]$ & & $=$ & \\
\hline & Total $(95 \% \mathrm{Cl})$ & & & 497 & & & 480 & $100.0 \%$ & $-0.08[-0.36,0.19]$ & & & \\
\hline & $\begin{array}{l}\text { Heterogeneity: Tau }{ }^{2}=0 \\
\text { Test for overall effect: } z\end{array}$ & $\begin{array}{l}.09 ; \mathrm{Chi}^{2} \\
=0.58(\mathrm{P}\end{array}$ & $\begin{array}{l}=21.96 \\
P=0.56\end{array}$ & 94, $d f=$ & $=5(P=0$. & $0.0005)$ & $: 1^{2}=77$ & & & -4 & $\begin{array}{lll}-1 & 0 & 1 \\
& 2 \\
\text { Placebo } & & \text { Zinc alone }\end{array}$ & 4 \\
\hline
\end{tabular}




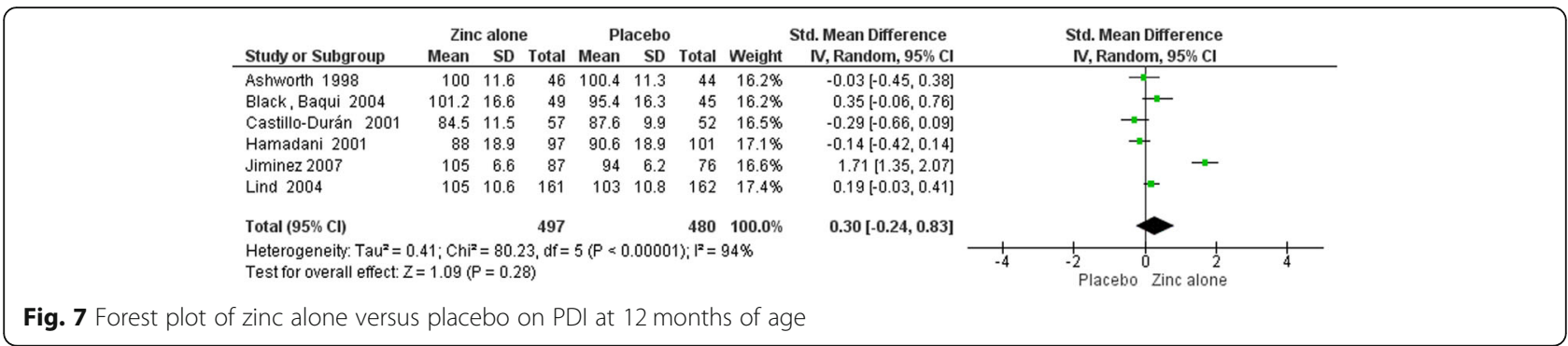

value: $0.36,591$ participants) and at 12 months of age (SMD: $0.30,95 \% \mathrm{CI}$ : -0.24 to 0.83 , P value: $0.28,977$ participants) with low quality evidence.

The results of two studies at 6 months assessment time and four studies at 12 months assessment time with BSID II were pooled to assess the effect of zinc with iron co-supplementation versus iron. There is moderate quality evidence that zinc with iron co-supplementation compared with iron does not have beneficial or adverse effect on MDI at 6 months of age (SMD: 0.09, 95\% CI: 0.11 to 0.30 , P value: $0.38,359$ participants), PDI at 6 months of age (SMD: 0.07, 95\% CI: - 0.14to 0.28, P value: $0.50,359$ participants), MDI at 12 months of age (SMD: -0.03 , 95\% CI: -0.17 to 0.11 , P value: $0.66,790$ participants) and PDI at 12 months of age (SMD: 0.01, 95\% CI: -0.24 to 0.26 , P value:0.93, 790 participants.).

\section{Qualitative analysis findings}

Seventeen studies data were not in meta-analysis and their results are summarized in Table 2.

In Bentley et al. study in 1997, motor development was assessed with observational method at 3 and 7 months of supplementation. The motor development of zinc group was better at 13 to 16 months of age however there was no difference in 9 to 12 months old [33]. In Gardner et al. study, 6 months supplementation with zinc in underweight children of 9-30 months old increased their hand and eye coordination [38]. Motor development at 10 months of age with daily zinc was not different in intervention and control group in Heinig et al. study [40]. In Katz et al. study, zinc with and without iron had no effect on mean age at first walking unassisted [42]. Locks et al. assessed child development with BSID third edition and showed that zinc supplementation had no effect on any domain of development at 15 months of age [44] .
In Mathur et al. study, attention span was better in zinc group at 40 weeks and higher number of excitability in control group at 40 weeks and 3 months old [45]. In Olney et al. study in 2006, zinc with and without iron supplementation in children 5-11 months of age had no effect on the time of unassisted walking. In Olney et al. study in 2013, effect of zinc with and without iron co supplementation in children 5-9 months old and 10-14 months old were assessed. Gross motor development at 5-9 months old and motor activity at 10-14 months old groups in zinc with iron co supplementation was better than control groups. Olney study in 2006 and Olney study in 2013 are two sub studies of Sazawal et al. study in 2006 [27]. In Prado et al. study, there was no difference in zinc and control group in motor development at 18 months of age [49]. In Sazawal et al. study, activity level were better in zinc group at 12 to 23 months old [50]. In Siegel et al. study, Zinc with and without iron had no effect on mental development at 39 and 52 weeks old [51]. In Surkan et al. study, zinc with and without iron had no effect on child motor development in 1 year supplementation in 4-17 months old infants [53]. Taneja et al. showed that 4 months supplementation with zinc alone had no effect in mental and motor development of children at 16-22 months of age [54].

Four studies assessed the long term effect of zinc supplementation with and without iron on child development in 6-9 year old children. All of them were supplemented before 36 months old [36, 46, 48, 52]. These studies showed that zinc supplementation with and without iron does not have any long term effect on child mental and motor development in school age. Christian et al. study showed that supplementation with zinc and iron up to 36 months of age had no developmental benefit at 7-9 year old children [36]. MurrayKolb showed that supplementation with zinc alone or

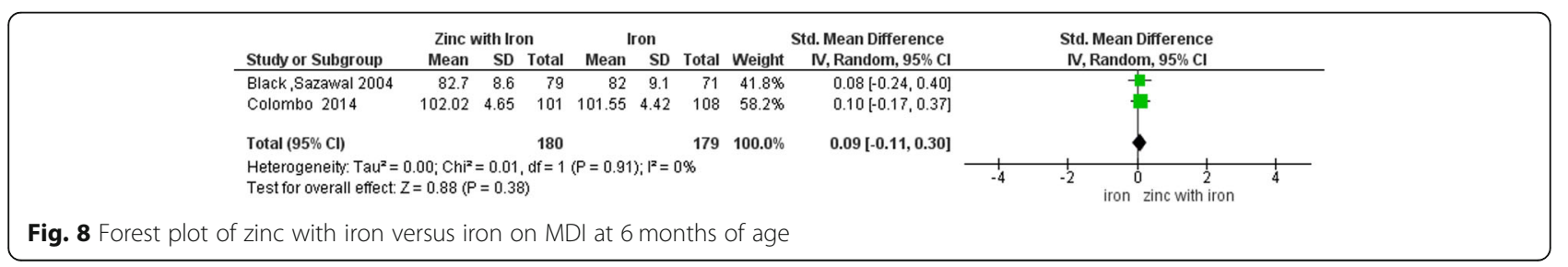




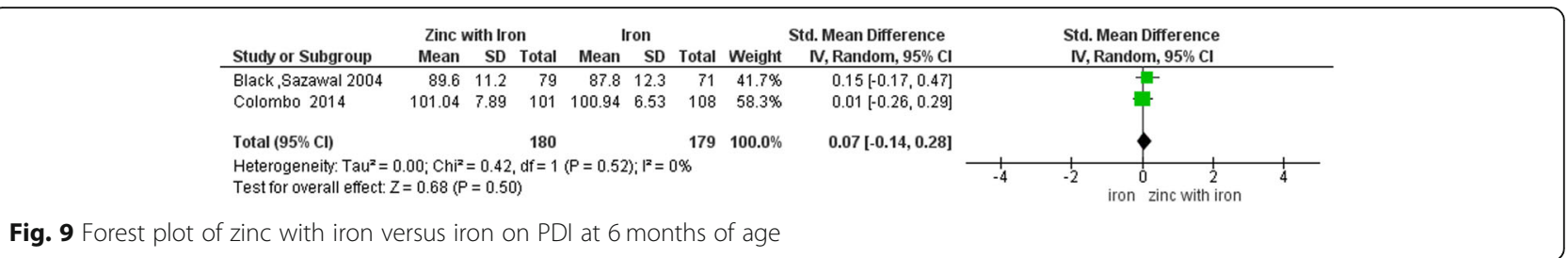

zinc and iron in 12 to 36 months old children do not have long term effect on 7-9 years old children mental and motor development. Murray- Kolb 2012 [46] and Katz 2010 [42] are from one original study in Nepal. Pongcharoen et al. study also showed that supplemented with zinc with and without iron for 6 months in 4-6 months old infants had no effect on their mental development at 9 years old [48]. Sudfeld et al. study is the follow up study of Locks study at 6-8 years old. They also showed that zinc supplementation up to 18 months of age had no effect on child development at school-age [52].

\section{Zinc effect in low and middle income countries}

Reviewing the final included studies in our study, we found that 23 of the trials were conducted in low and middle income countries. And two studies were carried out in high income countries. Four trials in low and middle income countries showed the efficacy of zinc alone on mental and/or motor development of children $[33,38,41,50]$ In addition, two studies in these countries showed positive effect of zinc with iron supplementation on child mental and/or motor development [22, $23]$. But the rest of the studies and trials in high income countries did not show any beneficial effects of zinc with and without iron supplementation on child development.

\section{Discussion}

In this systematic review and meta- analysis, we tried to answer, whether zinc alone or zinc with iron co-supplementation in children $0-5$ year old have any short or long term effect on child mental and motor development. It is possible that iron and zinc have molecular interactions with each other and zinc alone and zinc with iron co-supplementation have different effects on the children's developing body. It is also possible that zinc with iron could be better for development of children with lower z-score in the growth chart and children with malnutrition. Thus, we analyzed zinc alone and zinc with iron co-supplementation effect on child development in this systematic review and meta-analysis, separately.

The 6 and 12 months time points were chosen for meta- analysis, based on available data and with the consideration that exclusively breastfed infants may not benefit from zinc on 6 months of age because of enough intake of needed zinc from breast milk but infants may benefit from zinc supplementation at 12 months of age.

\section{Zinc alone supplementation effect on child development}

Twenty-one studies compared the effects of zinc alone with placebo on child development. Ten of them were multi arm intervention studies which we considered the zinc alone and placebo arms to be included in zinc alone assessment. One study showed beneficial effects of zinc on the child mental development [45], and four studies demonstrated the favorable effect of zinc supplementation on motor domain of child development [33, 38, 41, 50]. In addition, in one single study, zinc had adverse effect on mental development at 13 months of age [39]. In the rest of the studies, zinc had no statistically significant effect on child development. MDI and PDI in zinc alone group at 6 and 12 months of age did not have statistically significant results.

\section{Zinc co-supplementation with iron effect on child development}

Thirteen studies analyzed zinc with iron co-supplementation effect on child development. Nine of them were multi arm studies. We considered zinc with iron arm as intervention group and iron arm as their control group. In one study mental development was better in zinc with iron co-supplementation [22] compared to control group

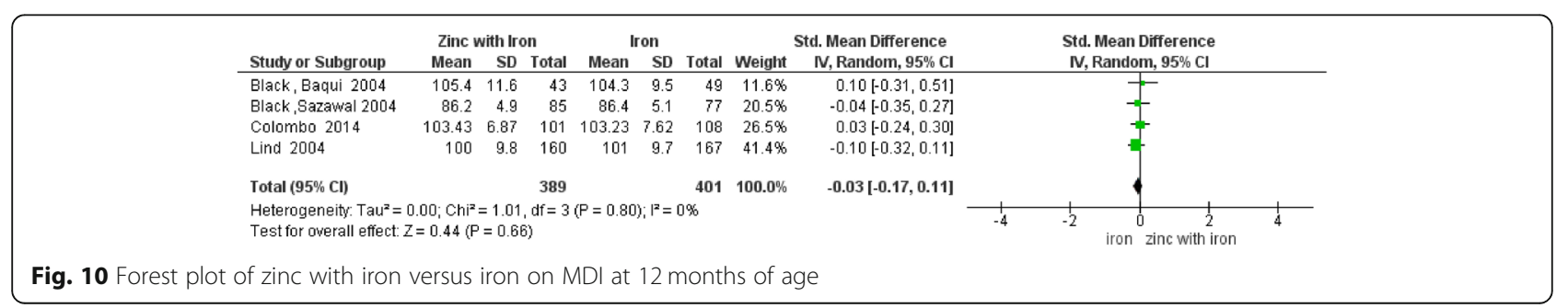




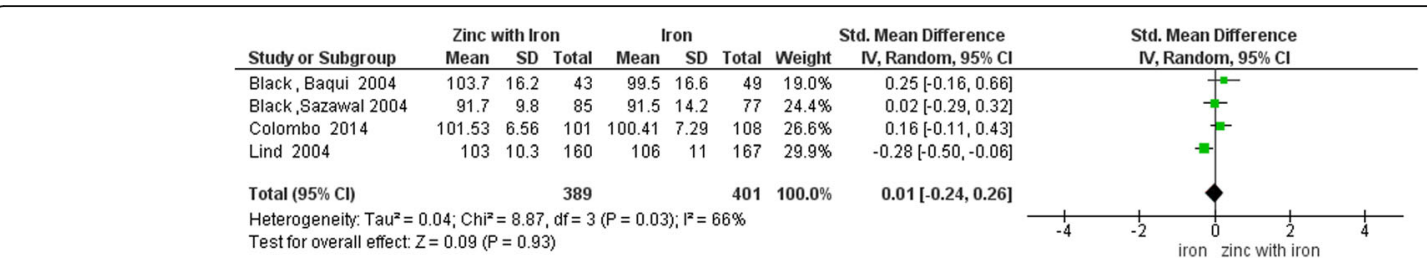

Fig. 11 Forest plot of zinc with iron versus iron on PDI at 12 months of age

whereas in another study zinc with iron had more positive effects on motor development [23]. In the rest of the studies, zinc with iron compared with iron had no statistically significant effect on child development. Comparisons of MDI and PDI in zinc with iron co-supplementation versus iron at 6 and 12 months of age did not have statistically significant results.

\section{Zinc supplementation effect on child development in school-age}

Christian, Murray-Kolb, Sudfeld and Pongcharoen and their colleagues, studied the effect of zinc intake with and without iron before 5 years of age on children development in 6-9 years old [36, 46, 48, 52]. They did not find any developmental difference in intervention and control groups. More long-term studies are needed to evaluate the impact of zinc with and without iron on older children.

\section{Quality of the evidence}

Using GRADE, we evaluated the certainty of the evidence to be moderate to low for described outcomes at 6 and 12 months of age in meta-analysis. The reasons for these judgments are outlined in GRADE certainty assessment Tables 2 and 3 in supplements.

Therefore, high quality RCTs are needed to confirm that zinc with and without iron have any positive or negative impact on child motor and mental development in children less than 1 year old.

\section{Limitations of the review}

The primary outcomes were to assess the effect of zinc with and without iron co-supplementation in children less than 5 years old on their short and long term mental and motor development however the data were not similar enough to do meta-analyses in children above 1 year old. So, the long term effect of zinc was not assessed in meta-analysis on child development and the results of 17 studies were reported descriptively.

To our best knowledge, the contextual influencing factors on association of zinc alone or iron supplementation with zinc on the children development are expectedly need to be addressed through sub-group and sensitivity analysis. These types of additional analysis surely lead to better understanding of those associations. But in our meta-analysis due to considerable differences in studies variables, we were not able to perform further analysis in this aspect. Of course we can assume any interpretation of the results should be accompanied with cautions, but in a general viewpoint we cannot confirm the positive impact of zinc alone or iron supplemented by zinc on children development.

\section{Conclusion}

In conclusion, no significant positive or negative effects on child mental and motor development were seen in zinc supplementation with or without iron groups compared with control groups at 6 and 12 months of age in Meta-analysis. Long term effects of zinc supplementation in children above 1 year old were not analyzed because of heterogeneity of outcome assessment tools. However, most of the studies showed that zinc with and without iron co-supplementation in children $0-5$ year old had no impact on child short and long term development up to 9 years old.

\section{Supplementary information}

Supplementary information accompanies this paper at https://doi.org/10. 1186/s12887-020-02340-1.

Additional file 1. Characteristics and risk of bias tables of all included studies.

Additional file 2: Table S1. MEDLINE (Ovid) search strategy. Table S2. GRADE assessments for zinc alone comparisons. Table S3. GRADE assessments for zinc with iron comparisons. Figure S1. Funnel plot of comparison Zinc alone versus Placebo, outcome: MDI at 6 months of age. Figure S2. Funnel plot of comparison Zinc alone versus Placebo, outcome: PDI at 6 months of age. Figure S3. Funnel plot of comparison Zinc alone versus Placebo, outcome: MDI at 12 months of age.

Figure S4. Funnel plot of comparison Zinc alone versus Placebo, outcome: PDI at 12 months of age. Figure S5. Funnel plot of comparison Zinc with Iron versus Iron, outcome: MDI at 6 months of age. Figure S6. Funnel plot of comparison Zinc with Iron versus Iron, outcome: PDI at 6 months of age. Figure S7. Funnel plot of comparison: Zinc with Iron versus Iron, outcome: MDI at 12 months of age. Figure S8. Funnel plot of comparison: Zinc with Iron versus Iron, outcome: PDI at 12 months of age.

\section{Abbreviations}

BSID: Bayley Scales of Infant Development; GRADE: Grading quality of evidence and strength of recommendations; MDI: Mental Developmental Index; MESH: Medical subject headings; PDI: Psychomotor Developmental Index; PRISMA: Preferred Reporting Items for Systematic Reviews and MetaAnalyses; RCT: Randomized controlled trials; SMD: Standardized Mean Difference 


\section{Acknowledgements}

The authors are greatly indebted to the Editor and reviewers for providing very useful comments and suggestions, which greatly improved the original manuscript of this paper.

We appreciate the financial and executive support of the University of Social Welfare and Rehabilitation Sciences.

\section{Authors' contributions}

FS, SF and SS had substantial contributions to the conception and design of the work; they had substantial contributions to acquisition, analysis, interpretation of data and drafting the work and revising it critically for important intellectual content. They had also contributed for final approval of the version to be submitted and they have agreed to be accountable for all aspects of the work in ensuring that questions related to the accuracy or integrity of any part of the work are appropriately investigated and resolved. HG and ZM had substantial contributions to the conception and design of the work, analysis, interpretation of data and revising the article for important intellectual content, and contributed to final approval of the version to be submitted. All authors have read and approved the manuscript.

\section{Funding}

This work was supported by the University of Social Welfare and Rehabilitation Sciences. The funders had no role in the design, data collection, analysis of neither the study, nor the decision to publish or the preparation of this manuscript.

\section{Availability of data and materials}

The datasets analyzed during the current study are not public, but are available from the corresponding author on reasonable request.

\section{Ethics approval and consent to participate}

Ethics approval for this study was granted by the Ethics Committee of University of Social Welfare and Rehabilitation Sciences.

\section{Consent for publication}

Not applicable.

\section{Competing interests}

The authors declare that they have no competing interests.

\section{Author details}

'Pediatric Neurorehabilitation Research Center, University of Social Welfare and Rehabilitation Sciences, Tehran, Iran. ${ }^{2}$ Health Economics Group, Institute of Health Research, Medical School, University of Exeter, Exeter, UK. ${ }^{3}$ Department of Physiotherapy, University of Social Welfare and Rehabilitation Sciences, Tehran, Iran. ${ }^{4}$ Department of Global Public Health, Karolinska Institutet, Stockholm, Sweden.

Received: 19 February 2020 Accepted: 13 September 2020 Published online: 28 September 2020

\section{References}

1. Dobbing J. Vulnerable periods in developing brain. In: Brain, behaviour, and iron in the infant diet. London: Springer; 1990. p. 1-17.

2. Sajedi F, Vameghi R, Kraskian MA. Prevalence of undetected developmental delays in Iranian children. Child Care Health Dev. 2014;40(3):379-88.

3. Vameghi R, Hatamizadeh N, Sajedi F, Shahshahanipoor S, Kazemnejad A. Production of a native developmental screening test: the Iranian experience. Child Care Health Dev. 2010;36(3):340-5.

4. Rosales FJ, Reznick JS, Zeisel SH. Understanding the role of nutrition in the Brain \& Behavioral Development of toddlers and preschool children: identifying and overcoming methodological barriers. Nutr Neurosci. 2009; 12(5):190-202.

5. DeLong GR. Effects of nutrition on brain development in humans. Am J Clin Nutr. 1993;57(2):286S-90S.

6. Blakemore LJ, Trombley PQ. Zinc as a neuromodulator in the Central nervous system with a focus on the olfactory bulb. Front Cell Neurosci. 2017;11:297.

7. Cousins RJ, McMahon RJ. Integrative aspects of zinc transporters. J Nutr. 2000;130(5S Suppl):1384s-7s.
8. Sandstead $\mathrm{HH}$. Zinc is essential for brain development and function. J Trace Elem Exp Med. 2003;16(4):165-73.

9. Dehghani SM, Katibeh P, Haghighat M, Moravej H, Asadi S. Prevalence of zinc deficiency in 3-18 years old children in shiraz-Iran. Iran Red Crescent Med J. 2011;13(1):4-8.

10. Morales-Ruan Mdel C, Villalpando S, Garcia-Guerra A, Shamah-Levy T, Robledo-Perez R, Avila-Arcos MA, et al. Iron, zinc, copper and magnesium nutritional status in Mexican children aged 1 to 11 years. Salud Publica Mex. 2012;54(2):125-34.

11. Wessells KR, Brown KH. Estimating the global prevalence of zinc deficiency: results based on zinc availability in national food supplies and the prevalence of stunting. PLoS One. 2012;7(11):e50568.

12. Brown KH, Engle-Stone R, Krebs NF, Peerson JM. Dietary intervention strategies to enhance zinc nutrition: promotion and support of breastfeeding for infants and young children. Food Nutr Bull. 2009;30(1 Suppl):S144-71.

13. Hess SY, Brown KH. Impact of zinc fortification on zinc nutrition. Food Nutr Bull. 2009;30(1 Suppl):S79-107.

14. Wessells KR, Ouedraogo ZP, Rouamba N, Hess SY, Ouedraogo JB, Brown KH. Short-term zinc supplementation with dispersible tablets or zinc sulfate solution yields similar positive effects on plasma zinc concentration of young children in Burkina Faso: a randomized controlled trial. J Pediatr. 2012;160(1):129-35.e3.

15. Krebs NF, Westcott JE, Culbertson DL, Sian L, Miller LV, Hambidge KM. Comparison of complementary feeding strategies to meet zinc requirements of older breastfed infants. Am J Clin Nutr. 2012;96(1):30-5.

16. Gogia S, Sachdev HS. Zinc supplementation for mental and motor development in children. Cochrane Database Syst Rev. 2012;12:Cd007991.

17. Nissensohn M, Sanchez-Villegas A, Fuentes Lugo D, Henriquez Sanchez P, Doreste Alonso J, Skinner AL, et al. Effect of zinc intake on mental and motor development in infants: a meta-analysis. Int J Vitam Nutr Res. 2013; 83(4):203-15.

18. de Brito NJN, de Medeiros Rocha ÉD, de Araújo SA, Costa JBS, França MC. das Graças Almeida M, et al. Oral zinc supplementation decreases the serum Iron concentration in healthy schoolchildren: a pilot study. Nutrients. 2014;6(9):3460-73.

19. Carter RC, Kupka R, Manji K, McDonald CM, Aboud S, Erhardt JG, et al. Zinc and multivitamin supplementation have contrasting effects on infant iron status: a randomized, double-blind, placebo-controlled clinical trial. Eur J Clin Nutr. 2018;72(1):130-5.

20. Olivares M, Pizarro F, Gaitán D, Ruz M. Acute inhibition of iron absorption by zinc. Nutr Res. 2007;27(5):279-82.

21. Peres JM, Bureau F, Neuville D, Arhan P, Bougle D. Inhibition of zinc absorption by iron depends on their ratio. J Trace Elem Med Biol. 2001; 15(4):237-41.

22. Black MM, Baqui AH, Zaman K, Ake Persson L, El Arifeen S, Le K, et al. Iron and zinc supplementation promote motor development and exploratory behavior among Bangladeshi infants. Am J Clin Nutr. 2004;80(4):903-10.

23. Olney DK, Kariger PK, Stoltzfus RJ, Khalfan SS, Ali NS, Tielsch JM, et al. Developmental effects of micronutrient supplementation and malaria in Zanzibari children. Early Hum Dev. 2013;89(9):667-74.

24. Moher D, Liberati A, Tetzlaff J, Altman DG. Preferred reporting items for systematic reviews and meta-analyses: the PRISMA statement. PLoS Med. 2009;6(7):e1000097.

25. Tielsch JM, Khatry SK, Stoltzfus RJ, Katz J, LeClerq SC, Adhikari R, et al. Effect of routine prophylactic supplementation with iron and folic acid on preschool child mortality in southern Nepal: community-based, clusterrandomised, placebo-controlled trial. Lancet (London, England). 2006; 367(9505):144-52.

26. McDonald CM, Manji KP, Kisenge R, Aboud S, Spiegelman D, Fawzi WW, et al. Daily zinc but not multivitamin supplementation reduces diarrhea and upper respiratory infections in Tanzanian infants: a randomized, doubleblind, placebo-controlled clinical trial. J Nutr. 2015;145(9):2153-60.

27. Sazawal S, Black RE, Ramsan M, Chwaya HM, Stoltzfus RJ, Dutta A, et al. Effects of routine prophylactic supplementation with iron and folic acid on admission to hospital and mortality in preschool children in a high malaria transmission setting: community-based, randomised, placebo-controlled trial. Lancet (London, England). 2006;367(9505):133-43.

28. Higgins JP, Altman DG, Gotzsche PC, Juni P, Moher D, Oxman AD, et al. The Cochrane Collaboration's tool for assessing risk of bias in randomised trials. BMJ (Clinical research ed). 2011;d5928:343. 
29. Ryan R, Hill S, Prictor M, McKenzie J. Cochrane Consumers and Communication Review Group. Study quality guide 2013

30. Ryan R, Hill S. How to GRADE the quality of the evidence: Cochrane Consumers and Communication. Group. 2016

31. Collaboration C. Review manager 5.3. Copenhagen: The Nordic Cochrane Centre; 2011.

32. Ashworth A, Morris SS, Lira PI, Grantham-McGregor SM. Zinc supplementation, mental development and behaviour in low birth weight term infants in Northeast Brazil. Eur J Clin Nutr. 1998;52(3):223-7.

33. Bentley ME, Caulfield LE, Ram M, Santizo MC, Hurtado E, Rivera JA, et al. Zinc supplementation affects the activity patterns of rural Guatemalan infants. J Nutr. 1997;127(7):1333-8.

34. Black MM, Sazawal S, Black RE, Khosla S, Kumar J, Menon V. Cognitive and motor development among small-for-gestational-age infants: impact of zinc supplementation, birth weight, and caregiving practices. Pediatrics. 2004; 113(5):1297-305

35. Castillo-Duran C, Perales CG, Hertrampf ED, Marin VB, Rivera FA, Icaza G. Effect of zinc supplementation on development and growth of Chilean infants. J Pediatr. 2001;138(2):229-35.

36. Christian P, Morgan ME, Murray-Kolb L, LeClerq SC, Khatry SK, Schaefer B, et al. Preschool iron-folic acid and zinc supplementation in children exposed to iron-folic acid in utero confers no added cognitive benefit in early school-age. J Nutr. 2011;141(11):2042-8.

37. Colombo J, Zavaleta N, Kannass KN, Lazarte F, Albornoz C, Kapa LL, et al. Zinc supplementation sustained normative neurodevelopment in a randomized, controlled trial of Peruvian infants aged 6-18 months. J Nutr. 2014;144(8):1298-305.

38. Gardner JM, Powell CA, Baker-Henningham H, Walker SP, Cole TJ, GranthamMcGregor SM. Zinc supplementation and psychosocial stimulation: effects on the development of undernourished Jamaican children. Am J Clin Nutr 2005;82(2):399-405.

39. Hamadani JD, Fuchs GJ, Osendarp SJ, Khatun F, Huda SN, GranthamMcGregor SM. Randomized controlled trial of the effect of zinc supplementation on the mental development of Bangladeshi infants. Am J Clin Nutr. 2001;74(3):381-6

40. Heinig MJ, Brown KH, Lonnerdal B, Dewey KG. Zinc supplementation does not affect growth, morbidity, or motor development of US term breastfed infants at 4-10 mo of age. Am J Clin Nutr. 2006;84(3):594-601.

41. Jiménez $R$, Martínez $M$, Peñalver R. Zinc effects on growth and development of infant with low birth weight. Colombia Médica. 2007;38(1): 6-13.

42. Katz J, Khatry SK, Leclerq SC, Mullany LC, Yanik EL, Stoltzfus RJ, et al. Daily supplementation with iron plus folic acid, zinc, and their combination is not associated with younger age at first walking unassisted in malnourished preschool children from a deficient population in rural Nepal. J Nutr. 2010; 140(7):1317-21.

43. Lind T, Lonnerdal B, Stenlund H, Gamayanti IL, Ismail D, Seswandhana R, et al. A community-based randomized controlled trial of iron and zinc supplementation in Indonesian infants: effects on growth and development. Am J Clin Nutr. 2004;80(3):729-36.

44. Locks LM, Manji KP, McDonald CM, Kupka R, Kisenge R, Aboud S, et al. The effect of daily zinc and/or multivitamin supplements on early childhood development in Tanzania: results from a randomized controlled trial. Matern Child Nutr. 2017;13(2):e12306.

45. Mathur NB, Agarwal DK. Zinc supplementation in preterm neonates and neurological development, A Randomized Controlled Trial. Indian Pediatr. 2015;52(11):951-5.

46. Prado EL, Abbeddou S, Yakes Jimenez E, et al. Lipid-Based Nutrient Supplements Plus Malaria and Diarrhea Treatment Increase Infant Development Scores in a Cluster-Randomized Trial in Burkina Faso. J Nutr. 2015;146(4):814-22.

47. Olney DK, Pollitt E, Kariger PK, Khalfan SS, Ali NS, Tielsch JM, et al. Combined iron and folic acid supplementation with or without zinc reduces time to walking unassisted among Zanzibari infants 5- to 11-mo old. J Nutr. 2006; 136(9):2427-34.

48. Pongcharoen $T$, DiGirolamo AM, Ramakrishnan U, Winichagoon P, Flores $R$, Martorell R. Long-term effects of iron and zinc supplementation during infancy on cognitive function at $9 \mathrm{y}$ of age in northeast Thai children: a follow-up study. Am J Clin Nutr. 2011;93(3):636-43.

49. Prado EL, Abbeddou S, Yakes Jimenez E, Some JW, Ouedraogo ZP, Vosti SA, et al. Lipid-Based Nutrient Supplements Plus Malaria and Diarrhea
Treatment Increase Infant Development Scores in a Cluster-Randomized Trial in Burkina Faso. J Nutr. 2016.

50. Sazawal S, Bentley M, Black RE, Dhingra P, George S, Bhan MK. Effect of zinc supplementation on observed activity in low socioeconomic Indian preschool children. Pediatrics. 1996;98(6 Pt 1):1132-7.

51. Siegel EH, Kordas K, Stoltzfus RJ, Katz J, Khatry SK, LeClerq SC, et al. Inconsistent effects of Iron-folic acid and/or zinc supplementation on the cognitive development of infants. J Health Popul Nutr. 2011;29(6):593-604

52. Sudfeld CR, Manji KP, Darling AM, Kisenge R, Kvestad I, Hysing M, et al. Effect of antenatal and infant micronutrient supplementation on middle childhood and early adolescent development outcomes in Tanzania. Eur J Clin Nutr. 2019;73(9):1283-90.

53. Surkan PJ, Siegel EH, Patel S, Katz J, Khatry SK, Stoltzfus RJ, et al. Zinc and iron supplementation on motor and language milestone scores of infants and toddlers. Nutrition (Burbank, Los Angeles County, Calif). 2013;29(3):5428.

54. Taneja S, Bhandari N, Bahl R, Bhan MK. Impact of zinc supplementation on mental and psychomotor scores of children aged 12 to 18 months: a randomized, double-blind trial. J Pediatr. 2005;146(4):506-11.

\section{Publisher's Note}

Springer Nature remains neutral with regard to jurisdictional claims in published maps and institutional affiliations.
Ready to submit your research? Choose BMC and benefit from:

- fast, convenient online submission

- thorough peer review by experienced researchers in your field

- rapid publication on acceptance

- support for research data, including large and complex data types

- gold Open Access which fosters wider collaboration and increased citations

- maximum visibility for your research: over $100 \mathrm{M}$ website views per year

At $\mathrm{BMC}$, research is always in progress.

Learn more biomedcentral.com/submissions 